\title{
Econometric Analysis of Socio-Economic Factors Affecting Smallholder Fish Production in Kabwe District, Zambia
}

\author{
Emmanuel Chibanda Musaba ${ }^{1 *}$, Enedy Namanwe ${ }^{2}$ \\ ${ }^{I}$ Mulungushi University, School of Agriculture and Natural Resources, P.O Box 80415, Kabwe, Zambia. \\ ${ }^{2}$ Ministry of Agriculture, Agriculture District Office, P.O BOX 80903, Kabwe, Zambia.
}

*Corresponding Author: Emmanuel Chibanda Musaba, Mulungushi University, School of Agriculture and Natural Resources, P.O Box 80415, Kabwe, Zambia.

\begin{abstract}
Over the past two decade, aquaculture production increased rapidly with the largest contribution to total fish production in the country coming from large-scale commercial fish farms while small-scale farmers made a small contribution. The objective of this study was to analyse the socio-economic factors affecting small-scale fish production in Zambia. Data were collected from 60 small-scale fish farmers who were purposively selected in Kabwe district in Central province. Data were analysed using descriptive statistics and multiple regression analysis. The regression results indicated that sex of the farmer, household size, farming experience, pond size, extension contact, chicken manure and distance to the market significantly affected production of smallholder fish in the study area. An increase in pond size, chicken manure, and farmer being male, led to an increase in smallholder fish production. On the contrary, an increase in farming experience and distance to the market, negatively affected smallholder fish production. The challenges facing smallholder fish production included: shortage of water resources, lack of credit, scarcity of high quality feed and fingerlings, fish theft and fish predators. The study recommended that policy measures should consider: provision of capital (credit) for construction of ponds in order increase pond area; improved supply of quality fingerlings and fish feed to farmers, encourage fish farmers to establish cooperative to facilitate fish marketing and, strengthen provision of extension services to train farmers in improved fish farming and management practices.
\end{abstract}

Keywords: fish farming, regression analysis, socio-economic variables

\section{INTRODUCTION}

Fish is an important source of protein to Zambians, providing53.4\% of dietary intake of animal protein (IAPRI, 2017). Fish in Zambia comes from two sources namely, capture fisheries and aquaculture. Since capture fisheries has low capacity to sustain the supply of fisheries products needed to meet the growing domestic demand of fish, a great opportunity has emerged for aquaculture to increase production and fill this gap in fish supply for human consumption (FAO, 2014).

The Zambian government has promoted aquaculture as an important tool in the fight against food insecurity, malnutrition and poverty. In addition aquaculture presents a good opportunity for diversification of the agriculture sector. Development of smallholder aquaculture farming has been the main focus of the National Aquaculture Strategy and the Development Plan (DoF 2015). Aquaculture farming systems in Zambia include cages, ponds, circulation tanks, and dams (Nsonga and Simbotwe 2014). Zambia has two types of aquaculture producers, namely: commercial and smallholder producers. The commercial fish farming is capital and labour intensive, use ponds, tanks, and cages, have high stocking densities of mono-sex fish species and rely on supplementary feeding using agricultural by-products such as maize bran, sunflower cake, brewery wastes, mill sweepings and chicken litter. It also involves greater control of the environmental pond parameters through application of compost organic manure or chemical fertilizer. The smallholder farming involves cultivation of fish mainly tilapia using small ponds and low input system in particular application of chicken manure for fertilizing ponds (Nsonga and Simbotwe, 2014).

For many decades capture fisheries was the dominant source of fish in Zambia. However, fish output from capture fisheries has been stagnant at 75,000 tonnes per annum for a long time and the growth in fish output in the country in recent times has been due to aquaculture development. During 2005- 
2015 , there was rapid growth of aquaculture production from 5,000 tonnes to 27,650 tonnes. This growth meant that at the end of 2015, the aquaculture sector contributed 24 percent of total fish production. The per capita fish production was $6.6 \mathrm{~kg}$ while the per capita fish consumption was 10.3 $\mathrm{kg}$ in 2013, indicating that imports were required to meet the gap between domestic demand and production. Importation of fish stood at 37\% of total domestic demand in 2016 (IAPRI 2017). The fish demand in the country continues to increase due to rapid population growth and rising incomes.

Within aquaculture sector, the smallholder producers who constitute majority of rural poor households, experience low productivity and production and consequently contribute a small share (30 percent) to aquaculture fish output. Given, that aquaculture is expected to play a leading role in the global fight against food insecurity, malnutrition and poverty (Bene and Heck 2005), low fish production performance of smallholder farmers in Zambia is a concern. If left unchecked the opportunity of aquaculture to improve smallholder livelihoods in Zambia is unlikely to be achieved. Therefore, there is a need to understand how various factors affect smallholder fish production in Zambia. Such knowledge would be useful to policy makers in the design of strategies for improving and strengthening smallholder aquaculture production in Zambia.

Empirical literature from developing countries on factors affecting smallholder fish production and productivity, indicated that most studies based on descriptive and regression analysis, found that the socio-economic factors affecting fish production include; age of the farmer, gender, farming experience, education, human labour, extension contact, access to credit, pond size, cost of land, fingerlings, and fish feed among others (Osondu and Ijioma 2014; Maina et al 2014; Awoyemi and Ajiboye 2011;Akenbor and Iken 2015; Okwu and Acheneje 2011; Abbas and Ukoje 2009). The constraints identified to affect fish production include: non-availability of quality fish seed and feed, high feed cost, poor extension services, poor marketing support, inadequate storage facilities, limited capital, poor power supply, predators, high cost of pond construction, high fish price and inadequate water supply (Akenbor and Iken 2015; Osundu et al 2014; Nsonga et al 2015, Musuka et al. 2013).The review indicated that there is a lack of empirical studies regarding socio-economic factors affecting smallholder fish production in Zambia. Therefore in order to fill this information gap, this study was initiated with the objective of analysing the socio-economic factors affecting smallholder fish production in Zambia.

\section{Methodology}

\subsection{Study Area, Design and Sampling Technique}

The study was conducted in Kabwe district, the provincial headquarters of Central Province. It is located $130 \mathrm{~km}$ north of Lusaka, the capital Zambia. It has a population of 202,914 people (CSO Census 2010). The district consists of 4 agricultural blocks, and each block is subdivided into 2-3 camps. Agricultural camp is the lowest level of agricultural administration and ideally is supposed to cover a radius of $15 \mathrm{~km}$. In Kabwe district there are eight agricultural camps. The district falls in agroecological zone II of Zambia.

Multi-stage and purposive sampling methods were used to select the respondents in this study. First Kabwe district was selected in the province, at stage two, four agricultural blocks (Waya, Munga, Mpima and Munyama) in Kabwe district were selected and final stage a purposive sample of 60 smallholder fish farmers who had stocked their ponds in 2013 and 2014 were selected from four agricultural blocks. The selection was guided by area extension staff. The respondents were interviewed using a questionnaire. The questionnaire sought information on socio-economic characteristics such as: gender, age, farm size, level of education, experiencein fish farming, extension contact, funding access, pond size, pond type, fish type, feed type, cost and quantity of fingerings, yield per year, fish price, market distance and constraints to fish farming. The information collected pertain to the production activities for one year (2014/15). Interviews were also conducted with staff from the provincial and district fisheries offices and agricultural camp staff to obtain supplementary information on issues and factors affecting fish farming in the local area.

\subsection{Data Analysis}

Descriptive statistics in terms of mean, frequency, and percentages were used to describe the characteristics of sample variables. Econometric analysis using linear multiple regression model was 
used to analyse the relationship between the socio-economic variables and fish production. The four functional forms namely, linear, exponential, semi-log and Cobb-Douglas wereanalysed and the lead equation selected based on certain econometric (high $\mathrm{R}^{2}$ value, F- ratio, number of significant factors) criteria as well as their conformity to apriori expectation.

\subsection{Econometric Model Specification and Estimation of Empirical Regression Model}

The empirical studies in the literature on fish production economics that have investigated the relationship between socio-economic variables and production and profitability have used multiple regression methods (Osundu et al 2015 and Nwapa et al. 2016). The socio-economic variables used in the studies conducted by Osundu et al (2015), Nwapa et al. (2016),Toma et al., (2016)included age, gender, educational status, household size, pond size, farming experience, extension access, credit access, farm income and distance, fingerling, feed cost, fertilizer, labour cost, electricity cost. The socio-economic variables included in this study were informed by the existent literature. The average annual fish output was used as the dependent variable $(\mathrm{Y})$ and the chosen nine socio-economic characteristics of the respondents were age, gender, education, household size, experience, extension contact, distance, chicken manure and pond size. The implicit model of the regression was specified as follows:

$$
\begin{aligned}
& \mathrm{Y}=\mathrm{f}\left(\mathrm{X}_{1}, \mathrm{X}_{2}, \mathrm{X}_{3}, \mathrm{X}_{4}, \mathrm{X}_{5}, \mathrm{X}_{6}, \mathrm{X}_{7}, \mathrm{X}_{8}, \mathrm{X}_{9}\right) \\
& Y i=\beta_{0}+\beta_{1} X_{1}+\beta_{2} X_{2}+\beta_{3} X_{3}+\beta_{4} X_{4}+\beta_{5} X_{5}+\beta_{6} X_{6}+\beta_{7} X_{7}+\beta_{8} X_{8}+\beta_{9} X_{9}+e_{i} \ldots \ldots \ldots \ldots \ldots \ldots .
\end{aligned}
$$

Where: $Y i$ is the dependent variable and $X_{i}(\mathrm{i}=1$ to 9 ) are independent socio-economic variables, $\beta$ are the parameters to be estimated, and $e_{i}$ is the error term.

Where:

$\mathrm{Y}_{\mathrm{i}}=$ Output of fish $(\mathrm{Kg})$

$\mathrm{X}_{1}=$ Age of respondent

$\mathrm{X}_{2}=$ Gender $(1=$ male; $0=$ female $)$,

$\mathrm{X}_{3}=$ Education level

$\mathrm{X}_{4}=$ Household size

$\mathrm{X}_{5}=$ Experience in fish farming (years),

$\mathrm{X}_{6}=$ Pond size $(\mathrm{sqm})$

$\mathrm{X}_{7}=$ Chicken manure used (dummy)

$\mathrm{X}_{8}=$ Extension service visit (dummy)

$\mathrm{X}_{9}=$ Distance to the market (kilometers)

$e_{i}=$ error term

The explicit functional forms tried were as follows:

Linear function: $Y i=b_{0}+b_{1} X_{1}+\ldots+b_{9} X_{9}+e_{i}$

Semi-Log function: $\quad Y i=b_{0}+b_{1} \operatorname{Ln} X_{1}+\ldots+b_{9} \operatorname{Ln} X_{9}+e_{i}$

Exponential function: $\quad L n Y i=b_{0}+b_{1} X_{1}+\ldots+b_{9} X_{9}+e_{i}$

Double-logfunction: $\quad \operatorname{LnYi}=b_{0}+b_{1} \operatorname{LnX} X_{1}+\ldots+b_{9} \operatorname{LnX} X_{9}+e_{i}$

Apriori Expectation: Some of the variables (gender, education, household size, farming experience, pond size, extension contact, and chicken manure use) were expected to positively influence total fish production. While distance to the market were expected to have negative impact on total fish production. The impact of age of the farmer on fish production was expected to be ambiguous.

Prior to estimation the variables were tested for presence of multicollinearity using variance inflation factor (VIF). Data was also tested for presence of heteroscedasticity using Breuch-Pagan test. The presence of multicollinearity in the data was ruled out on basis of VIF values being less than 10 . The 
Breuch-Pagan test did not find heteroscedasticity in the data. The analysis was conducted using STATA 10.

After the estimation of the regression model using the four functional forms viz: linear, semilogarithmic, exponential and double logarithmic, the lead equation chosen was the exponential function based on statistical significance, conformity with economic theory (production function) and the apriori expectation of the variables. The discussion of the regression results will focus on the estimated exponential function.

\section{RESULTS AND DISCUSSION}

\subsection{Socio-Economic Characteristics of the Respondents}

Table 1 shows the socio-economic characteristics of respondents. Majority of the farmers were male (90\%) and 10\% were female. This indicates that females are less likely to adopt fish farming because due to their high work load and because a lot of physical labour is required in the construction and management of ponds. This confirms the findings of Maina et al. (2014) that pond construction is labour intensive and is mostly done by men and as such many women or female headed households are discouraged to venture into fish farming

The age distribution showed that $4.9 \%$ of respondents were aged between $31-40$ years (young age), 43.9\% were between $41-50$ years (middle age), and 51.2\% were above 50 years (old age). The average age of respondents was 50.5 years. This indicates that fish farming is undertaken mostly by people in the old age group those above 50 years and these are mainly retirees and it implies that aquaculture is not attracting the interest of the younger generation.

Household sizes ranged from 1 to 16 persons with a mean household size of 7.8 persons. In the sample $22 \%$ of respondents had household size of $1-5$ persons, $17 \%$ had $11-16$ persons and the majority (61\%) had 6-10 persons and fall in middle size family. This indicates that majority of farmers have adequate family labour and rely on family labour for fish pond management practices.

Education is an important socioeconomic factor while considering the productivity of any farming enterprise. It was observed that only a few respondents (2\%) had no formal education, $26.8 \%$ had primary education, majority $(46.3 \%)$ had secondary education and $24.4 \%$ had tertiary education. This suggests that most respondents were able to read and write and thus were aware of news enterprises and were getting involved. According to Osundu et al (2014), education enhances the acquisition and utilization of information on improved technology by farmers and tend to positively influence productivity.

It is known that experience in fish farming has positive influence on fish production (Kumar et al., 2015). Table 2 showed that $31.7 \%$ of respondents had 1-5 years of fish farming experience, $39 \%$ had 6-10 years, and 29.3\% had 11-16 years. The average years of fish farming experience was 8 years. This indicates that fish farming is relatively new practise in the study area since majority of respondents have been practising fish farming for 6-10 years.

A total of $93 \%$ of the fish farmers were visited by government extension workers. However a smaller proportion participated in activities organised by extension namely; agriculture shows (44\%), trainings (37\%) and field days (27\%).

Majority (63\%) of respondents reared red bream and 39\% reared tilapia. For fertilizing fish ponds, majority $(80.5 \%)$ of respondents used chicken manure and only $36.5 \%$ used purchased commercial fish feed.

Most (85.3\%) respondents owned earthen ponds and $19.5 \%$ owned concrete ponds. The number of ponds owned ranged from 1 to 10 , with a mean of 2.5 ponds per farm. Pond size ranged from 30 to 2,000 square meters, and average pond size was 426 square meters $\left(\mathrm{m}^{2}\right)$.

Table1. Socio-economic characteristics of respondents

\begin{tabular}{|c|c|c|}
\hline Variable & Frequency & Percentage \\
\hline Gender & & 9.8 \\
\hline Female & 4 & 90.2 \\
\hline Male & 37 & \\
\hline
\end{tabular}


Econometric Analysis of Socio-Economic Factors Affecting Smallholder Fish Production in Kabwe District, Zambia

\begin{tabular}{|c|c|c|}
\hline Total & 41 & 100.0 \\
\hline \multicolumn{3}{|l|}{ Age (Years) } \\
\hline $31-40$ & 2.0 & 4.9 \\
\hline $41-50$ & 18 & 43.9 \\
\hline Above 50 & 21 & 51.2 \\
\hline Total & 41.0 & 100.0 \\
\hline \multicolumn{3}{|l|}{ Household size (Persons) } \\
\hline $1-5$ & 9.0 & 22.0 \\
\hline $6-10$ & 25.0 & 61.0 \\
\hline $11-16$ & 7.0 & 17.1 \\
\hline $\begin{array}{r}\text { Total } \\
\end{array}$ & 41.0 & 100.0 \\
\hline \multicolumn{3}{|l|}{ Level of education } \\
\hline No Formal Education & 1 & 2.4 \\
\hline Primary & 11 & 26.8 \\
\hline Secondary & 19 & 46.3 \\
\hline Tertiary & 10 & 24.4 \\
\hline Total & 41 & 100.0 \\
\hline \multicolumn{3}{|l|}{ Experience } \\
\hline $1-5$ & 13 & 31.7 \\
\hline $6-10$ & 16 & 39.0 \\
\hline $11-16$ & 12 & 29.3 \\
\hline Total & 41 & 100.0 \\
\hline \multicolumn{3}{|l|}{ Extension Visit } \\
\hline No & 3 & 7.3 \\
\hline Yes & 38 & 92.7 \\
\hline Total & 41 & 100.0 \\
\hline \multicolumn{3}{|l|}{ Ponds (Number) } \\
\hline $1-3$ & 33.0 & 80.5 \\
\hline $4-6$ & 6.0 & 14.6 \\
\hline $7-10$ & 2.0 & 4.9 \\
\hline Total & 41.0 & 100.0 \\
\hline \multicolumn{3}{|l|}{ Pond area $\left(\mathrm{m}^{2}\right)$} \\
\hline $30-100$ & 8 & 19.5 \\
\hline $101-300$ & 12 & 29.3 \\
\hline $301-500$ & 12 & 29.3 \\
\hline $501-700$ & 1 & 2.4 \\
\hline $700-2000$ & 8 & 19.5 \\
\hline Total & 41 & 100.0 \\
\hline \multicolumn{3}{|l|}{ Chicken manure used } \\
\hline No & 8 & 19.5 \\
\hline Yes & 33 & 80.5 \\
\hline $\begin{array}{c}\text { Total } \\
\end{array}$ & 41 & 100.0 \\
\hline \multicolumn{3}{|l|}{ Distance to market (Km) } \\
\hline $1-10$ & 19.0 & 46.4 \\
\hline $11-20$ & 15.0 & 36.6 \\
\hline $21-30$ & 5.0 & 12.2 \\
\hline $30-40$ & 2.0 & 4.9 \\
\hline Total & 41.0 & 100.0 \\
\hline
\end{tabular}

Average age $=50.5$ years; average household size $=7.83$ persons; Mean pond size $=426 \mathrm{~m} 2$

Table 1 shows that $19.5 \%$ of respondents had between $30-100 \mathrm{~m} 2,29 \%$ had between $101-300 \mathrm{~m} 2$, $29 \%$ had between $300-500 \mathrm{~m} 2,2.4 \%$ had between $500-700 \mathrm{~m} 2$ and $19.5 \%$ had above $700 \mathrm{~m} 2$.

The ponds were stocked with fingerlings sourced from sources mostly located outside the central province. A third (29\%) of respondents obtained fingerlings from neighbours, $29 \%$ from Chirundu, $20 \%$ from Kalimba farms in Lusaka, 12\% from Mwekera Aquaculture Development Center in Kitwe, and $7 \%$ from Kariba.

Most fish farms were located between 1-10 km and 11-20 kilometres $(\mathrm{km})$ away from the market and the average distance was $14.2 \mathrm{~km}$. Less than $20 \%$ of respondents were located beyond $20 \mathrm{~km}$ from the market. 
The mean fish output per farm household was $254.7 \mathrm{~kg}$ and of which $233.8 \mathrm{~kg}$ was sold and the remainder was for home consumption. This indicates that a greater proportion of the fish produced was for sale and this suggests that the main reason for engaging in fish farming is for income generation rather than subsistence. However, fish yield was $89.7 \mathrm{~kg}$ per 150 square meters of fish pond was acceptable compared to observed fish yields in other parts of Zambia. Studies conducted in Northern Province (Nsonga, 2015; Kaminski et al., 2017) observed that the average productivity were generally between $10 \mathrm{~kg}$ per $150 \mathrm{~m} 2$ and $50 \mathrm{~kg}$ per $150 \mathrm{~m} 2$ or $0.5 \mathrm{mt} / \mathrm{ha}$ and $1.06 \mathrm{mt} / \mathrm{ha}$ per year depending on the conditions of production.

\subsection{Multiple Regression Estimates of the Socio-Economic Factors Affecting Smallholder Fish Production}

The regression estimates of socio -economic factors affecting the production of fish are shown in the Table 2 for the exponential function which was the lead equation. The coefficient of determination (R2) was0.691, meaning that $69.1 \%$ of variability in the dependent variable (fish production) was accounted for by the independent variables in the model. The model has F-ratio value of 9.69, with $\mathrm{p}=0.001$, indicating that the model was statistically significant at $1 \%$ level.

Out of the nine explanatory variables included in the model, the coefficients of six variables namely age, experience, pond size, chicken manure, extension visit, and distance to the market, had significant impact on fish production. While gender, education and household sizehad no statistically significant impact on fish production. All the parameters had the expected signs except for experience and extension access which had negative signs contrary to apriori expectations.

Table2. Multiple regression estimates of the socio-economic factors affecting smallholder fish production.

\begin{tabular}{|c|c|c|c|c|c|}
\hline Inharve 2013 & Coef. & Std. Err. & t & P>t & Elasticity \\
\hline Constant & $3.604^{* * *}$ & 0.846 & 4.26 & 0.000 & \\
\hline Age & $0.029^{*}$ & 0.015 & 1.93 & 0.064 & 1.464 \\
\hline Gender & 0.488 & 0.310 & 1.57 & 0.128 & 0.434 \\
\hline Education & 0.066 & 0.124 & 0.53 & 0.601 & 0.123 \\
\hline Household size & 0.039 & 0.035 & 1.11 & 0.277 & 0.307 \\
\hline Experience & $-0.06^{*} *$ & 0.025 & -2.36 & 0.026 & -0.512 \\
\hline Pondarea & $0.001^{* *}$ & 0.000 & 3.04 & 0.005 & 0.299 \\
\hline Marketdistance & $-0.028^{* *}$ & 0.011 & -2.63 & 0.014 & -0.408 \\
\hline Extension visit & $-0.832^{*}$ & 0.388 & -2.14 & 0.042 & -0.762 \\
\hline Chickenmanure & $0.847^{* *}$ & 0.246 & 3.44 & 0.002 & 0.659 \\
\hline \multicolumn{7}{|c|}{ Dependent variable: Fish production Adj $\mathrm{R}^{2}=0.691$ F=9.69 p=0.000, N=36 } \\
\hline
\end{tabular}

$* * *, * *, *$ refer to ignificance at $1 \%, 5 \%$ and $10 \%$, respectively. Values in parentheses are t-ratios.

Source: Field Survey 2015;

The regression result showed that fish production was positively and significantly related toage of the farmer, pond area, and fertilizing ponds with chicken manure. On the other hand, fish farming experience, extension contact (visits) and distance to the market had significant negative relationship with fish production in the study area.

The coefficient of age of the farmer was positive and significant at $10 \%$ probability level. This meant that the older the farmer, the higher the fish output. This is contrary to apriori expectation of a negative effect of age on production because older farmers are risk averse making them late adopters of better fish farming technologies. However, it agrees with the argument that older farmers tend to have more resources under their control than younger farmers which enable them to achieve higher output than younger farmers.

Farming experience in fish farming was significant at $5 \%$ probability and negatively related to fish production. The elasticity of fish production with respect to farming experience was -0.51 . This meant that a one percent increase in fish farming experience would decrease fish production by 0.51 percent. This result was contrary to the expected positive effect of experience on fish production as found by Osundu et al. (2014) and Oputa (2005). This negative effect of experience on fish production can be attributed to poor management of the fish ponds, lack of resources (low water levels in ponds on account of poor rainfall) and practising traditional or subsistence farming methods which do not lead to productivity or production improvement. 
The coefficient for pond area was significant and positively related to fish production. This meant that an increase in pond area would result in increased fish production. The increase in pond area (i.e. number and size of ponds) lead to increased stocking rate and use of other inputs which would result to increased output. This finding agrees with apriori expectations and is consistent with other studies including Onwuka (2005), Oputa (2005), Singh (2007) and Ezeh et al. (2008) and Osondu and Ijioma (2014) who obtained similar results.

Chicken manure use to fertilize fish ponds has a significant and positive influence on fish production. This finding implied that increasing the amount of chicken manure used as per recommended rates would lead to higher fish production. The finding is consistent with apriori expectation that fertilizing fish ponds with chicken manures increases fish production. This finding agrees with the study by Kapanda et al (2003) which found that animal manure use in fertilizing fish ponds in Malawi increased fish production.

Extension contact was significant at 5\% probability level and negatively related to fish production. This implied that any increase in extension contact would lead to a decrease in fish production in the study area. The finding was inconsistent with apriori expectation. The result contrast finding of studies (Nwaobiala 2014) that frequency of extension contact was a viable means of adoption of innovations for improving production. The negative effect of extension contact could imply that extension service was not delivering messages relevant to fish farmers and or farmers do not follow the extension recommendations (Awoniyi et al, 2006).

Distance to market was significant and negatively related to fish production. This meant that as distance increased from the farm to the market fish production decreased. This finding agrees with apriori expectations. As distance to the market increases, it increases transportation costs, fish spoilage and reduces returns to fish production and discourage fish production. Fish production is likely to flourish at farms located closer to market or consumption area.

\subsection{Problems Encountered by Fish Farmers in Kabwe District}

Table 3 shows that unavailability adequate water is a major constraint to fish farming in Kabwe reported by majority of respondents $(80.5 \%)$. Many farmers depend on intermittent streams which dry up during dry season. The second constraint was lack of funds $(50 \%)$. It was followed by theft (26.8\%), predators $(21.9 \%)$, lack of improved fish farming skills $(19.6 \%)$, and problems in sourcing of fingerlings (14.6\%), high fish feed cost, and poor access to reliable fish markets (14.6\%).

Table3. Problems encountered by fish farmers in Kabwe district $(n=41)$

\begin{tabular}{|c|c|}
\hline Problem & Percent of total sample \\
\hline Inadequate water availability & 80.5 \\
\hline Lack of funds & 50.0 \\
\hline Theft & 26.8 \\
\hline Predators & 22.0 \\
\hline Fish farming knowledge/skills & 19.5 \\
\hline Source fingering & 14.6 \\
\hline Non-availability commercial feed high cost & 14.6 \\
\hline No market or big reliable outlet & 14.7 \\
\hline Extension visits & 9.8 \\
\hline High transport cost & 4.9 \\
\hline Labour intensive /demanding & 4.9 \\
\hline
\end{tabular}

Source: Field survey, 2015

\section{CONCLuSion}

Smallholder fish farming has emerged as an important tool in the fight against food insecurity, malnutrition and poverty in most developing countries including Zambia. It also helps smallholder farmers to diversify their farm activities and improve income. Despite, smallholder farmers being majority of rural poor households they account for a small share (30 percent) of aquaculture fish output in Zambia. The study examined socio-economic factors affecting small-scale fish production using data from Kabwe district in central province of Zambia. The regression results indicated that age of the farmer, farming experience, pond size, extension contact, chicken manure and distance to 
the market and extension services significantly affected production of smallholder fish in the study area. An increase in pond size, chicken manure, led to an increase in smallholder fish production. On the contrary, an increase in farming experience and distance to the market, negatively affected smallholder fish production. The challenges facing smallholder fish production included: shortage of water resources, lack of credit, scarcity of high quality feed and fingerlings, fish theft and fish predators. The implications of the findings are that fish production in the study area could be increased through expansion of pond size, increased use of chicken manure in existing ponds through intensification.There is also need to consider: provision of capital (credit) for construction of ponds in order increase pond area; support improved supply of quality fingerlings and fish feed to farmers, encourage fish farmers to establish cooperative to facilitate fish marketing and, strengthen provision of extension services to train farmers in improved fish farming and management practices.

\section{ACKNOWLEDGEMENT}

The authors are grateful to small-scale fish farmers of Kabwe district for their cooperation in proving information used in this study.

\section{REFERENCES}

[1] Abbas, I.I and Ukoje J.A. 2009. Rural water utilization: Factors affecting aquaculture in Owo local government area of Ondo State, Nigeria. Journal of Geography and Regional Planning Vol. 2(8), pp. 190197, August, 2009 http://www.academicjournals.org/JGRP ISSN 2070-1845

[2] Akenbor, A. S. Ike, P.C. 2015. Analysis of Technical Efficiency of Catfish Farming in Edo State, Nigeria Journal of Biology, Agriculture and Healthcare Vol.5, No.2, 2015, p.96-99

[3] Awoniyi, O A., Omonona, B. T. 2006. Production Efficiency in Yam Based enterprises in Ekiti state, Nigeria. Journal Central European Agriculture. Vol 7. (4): 627-636.

[4] Awoyemi, T.T and Ajiboye, A.J. 2011. Analysis of profitability of fish farming among women in Osun State, Nigeria. Journal of Economics and Sustainable Development, 2: 1-8.

[5] Awoyemi, T.T, Amao J.O. and N.C. Ehirim (2003). Technical Efficiency in aquaculture in Oyo State, Nigeria. Indian Journal of Agricultural Economics, Vol.58, No.4, Oct-Dec, pp. 812-819.

[6] Bene C. and Heck S. 2005. Fish and Food Security in Africa. NAGA. World Fish Centers. Quarterly, 28 (3-4): 8-13.

[7] CSO (Central Statistics Office) 2010 National Population Census of the Republic of Zambia. Central Statistics Office, Lusaka, Zambia.

[8] DoF (Department of Fisheries Zambia) 2015. Fisheries and Aquaculture Statistics: Annual Report. Chilanga, Zambia.

[9] Ezeh C I, Anene A, Anya I P 2008. Socioeconomic and profitability of pond cat-fish production in Abia State, Nigeria. J. Food and fibre Prod. 1(1):127-136

[10] Food and Agriculture Organization of the United Nations (FAO) 2014. The State of World Fisheries and Aquaculture: Opportunities and challenges. FAO, Rome.

[11] IAPRI (Indaba Agricultural Policy Research Institute) 2017. Agriculture Status Report 2017. Indaba Agricultural Policy Research Institute, Lusaka, Zambia

[12] Kapanda K N, Ng'ong'ola D H, Matiya G G, Tchale H, Jamu D, and Kaunda E W K. 2003. Factors affecting adoption of fish farming in Malawi: A case of Mchiji Rural Development Programme. Aqua-Fish tech. Rep. Issue (2):34-38.

[13] Kaminski, A.M. 2017. Aquaculture, https://doi.org/10.1016/j.aquaculture.2017.12.010

[14] Kumar, P., Khar, S, Sharma, R., Choudhary, P., Himabindu, K.V, Sharma, S., Sharma, S.K, Jagmohan, S. 2015. Identifying Socio-economic features of fish farmers. An International Journal of Agro Economist vol. 2 (6): 255-258.

[15] Maina J.G, Mbuthia P. G, Ngugi J., Omolo B., Orina P., Wangia S. M., Karuri E. G., Maitho T and Owiti G O 2014 Influence of social-economic factors, gender and the Fish Farming Enterprise and Productivity Project on fish farming practices in Kenya, Livestock Research for Rural Development 26 (2) 2014

[16] Musuka G.C. and Musonda F. 2012. Contribution of small water bodies and smallholder aquaculture towards poverty alleviation and enhancing household food security in Zambia. International Journal of Fisheries and Aquaculture 5(11):295-302.

[17] Nsonga A. 2015. Status quo of fish farming in the Northern Province of Zambia a case for Mbala and Luwingu districts. International Journal of Aquatic Studies 2(2):232-237. 
[18] Nsonga A. and Simbotwe M. 2014. Challenges and emerging opportunities associated with aquaculture development in Zambia. International Journal of Aquatic Studies 2(2):232-237.

[19] Nwaobiala, C.U. 2014. Adoption of fish production technologies among homestead catfish farmers in Ebonyi state, Nigeria. Journal of Applied Agricultural Research 6(2):75-84.

[20] Nwapa K, Enwerem R. and Obianuju I. 2016. A study of profitability and production determinants of fish farming in Umuahia Capital Territory of Abia State, Nigeria. African Journal of Agricultural Economics and Rural Development 4 (2): 314-321.

[21] Okwu O.J. and Achenje S. 2011. Socio-Economic Analysis of Fish Farming in Makurdi Local Government Area, Benue State, Nigeria. European Journal of Social Sciences 23 (4): 508-519.

[22] Oputa C.O. 2005. Resource use and efficiency of Artisanal Fishing in Oguata L.G.A of Imo state. Department of Agricultural Economics and Extension. Abia State University Uturu Nigeria.

[23] Osondu C.K. and Ijioma J.C.2014. Analysis of profitability and production determinants of fish farming in Umuahia Capital Territory of Abia State, Nigeria. World Journal of Agricultural Sciences 2(7):165-176.

[24] Singh, K. 2007.Economics and determinants of fish production and its effects on family income Inequality in west Tripura District of Tripura. Indian journal of Agric. Econ. Vol. 62 (1):113-125.

[25] Wetengere K. 2009. Socio-economic factors critical for adoption of fish farming technology: The case of selected villages in Eastern Tanzania. International journal of fisheries and aquaculture 1 (2): 28 - 37.

Citation: Emmanuel Chibanda Musabal \& Enedy Namanwe, "Econometric Analysis of Socio-Economic Factors Affecting Smallholder Fish Production in Kabwe District, Zambia” International Journal of Research Studies in Agricultural Sciences (IJRSAS), 2020; 6(2), pp. 5-13, http://dx.doi.org/10.20431/24546224.0602002

Copyright: (c) 2020 Authors. This is an open-access article distributed under the terms of the Creative Commons Attribution License, which permits unrestricted use, distribution, and reproduction in any medium, provided the original author and source are credited. 